\title{
UPAYA YANG DAPAT DILAKUKAN OLEH KORBAN/ PENGGUNA JALAN MEMINTA PERTANGGUNGJAWABAN PIDANA PENYELENGGARA JALAN ATAS TERJADINYA KECELAKAAN AKIBAT JALAN RUSAK
}

\author{
Muhammad Taufiq Anshari Siregar \\ Fakultas Hukum Universitas Muhammadiyah Sumatera Utara, Medan \\ Mtaufiq07@yahoo.com
}

\begin{abstract}
Abstrak
Banyak faktor yang menyebabkan terjadinya kecelakaan di jalan raya. Faktor tersebut diantaranya jalan rusak. Jalan rusak sesuai dengan regulasi yang ada menjadi tanggungjawab pemerintah dalam hal ini adalah penyelenggara jalan, baik itu pemerintah pusat, pemerintah daerah baik propinsi maupun kabupaten/kota. Kewajiban penyelenggara jala tersebut ternyata berdasarkan fakta di lapangan sering kali terjadi kerusakan jalan dibiarkan oleh penyelenggara jalan hingga akhirnya beberapa kasus kecelakaan disebabkan karena jalan rusak yang dibiarkan dan tidak diperbaiki. Berdasarkan hasil penelitian bahwa upaya yang dapat dilakukan oleh korban/pengguna jalan meminta pertanggungjawaban pidana penyelenggara jalan atas terjadinya kecelakaan jalan akibat jalan rusak adalah melalui mekanisme citizen law suit. Pengertian dari citizen law suit adalah gugatan warga Negara yang ditujukan kepada Pemerintah atau negara akibat pelanggaran-pelanggaran hukum yang dilakukan negara dan dianggap merugikan kepentingan publik. Upaya lainnya adalah tanggung gugat merupakan kewajiban untuk menanggung ganti kerugian sebagai akibat pelanggaran norma.
\end{abstract}

Kata kunci: upaya, korban, jalan rusak, pertanggungjawaban, pidana

\section{PENDAHULUAN}

Lalu lintas dan angkutan jalan merupakan hal penting dalam meningkatkan mobilitas sosial masyarakat, sehingga Negara merasa penting untuk mengaturnya sesuai dengan perkembangan zaman agar terjaganya hak-hak warga negara dalam kegiatan lalu lintas dan angkutan jalan. Lalu lintas dan angkutan jalan (LLAJ) merupakan hal yang sangat dekat dengan masyarakat. Setiap waktu masyarakat terus bergulat dengan angkutan jalan dengan bermacam-macam kepentingan. Dalam hal ini warga negara butuh agar hak-haknya dalam berlalu lintas dijamin dan dilindungi oleh negara.

Negara sebagai sebuah organisasi tertinggi dari masyarakat berkewajiban menjamin dan melindungi hak-hak warga negaranya dijalan. Pemerintah mempunyai tujuan untuk mewujudkan lalu lintas dan angkutan jalan yang selamat, aman, cepat, lancar, tertib, teratur, nyaman, dan efisien melalui aturan perundang-undangan yang ada, yaitu Undang-Undang Republik Indonesia Nomor 22 Tahun 2009 tentang Lalu Lintas dan Angkutan Jalan (selanjutnya ditulis dengan UU LLAJ).

Faktor penyebab terjadinya kecelakaan disebabkan karena faktor manusia, faktor jalan, faktor kendaraan, faktor cuaca dan disebabkan karena penerangan jalan yang kurang memadai, tapi jalan rusak menyumbang potensi kecelakaan tertinggi serta minimnya infrastruktur. Infrastruktur jalan yang kurang memadai ikut berperan karena sering terjadinya kecelakaan lalu lintas, misalnya karena jalan tanpa lampu, jalan bertikungan tajam, tiada pagar pengaman dan geometris jalan tidak mendukung. Salah satu faktor penyebab terjadinya kecelakaan lalulintas adalah kondisi jalan yang rusak.

Telah banyak korban jatuh akibat jalan yang rusak tersebut, sehingga menimbulkan kerugian tidak hanya terhadap rusaknya kendaraan namun juga telah menghilangkan nyawa seseorang. Pada sisi lain, masyarakat sebagai pengguna jalan banyak yang tidak mengetahui terkait upaya yang dapat dilakukan untuk meminta pertanggungjawaban pidana penyelenggara jalan akibat jalan rusak.

Ada banyak kasus karena jalan yang rusak mengakibatkan timbulnya korban jiwa dan berlanjut ke pengadilan untuk menuntut pertanggungjawaban pemerintah, karena lalai memperbaiki jalan yang rusak. Gugatan ahli waris Almarhum Santun Silaban dengan melakukan pengajuan gugatan atas tuntutan ganti kerugian kepada pemerintah sebagai pengelola badan jalan, yang tertuang dalam putusan Pengadilan Negeri Pematang Siantar Nomor 21/Pdt.G/2013/PN. Pms dan juga gugatan Keluarga Almarhum Ponti Kadron Nainggolan yang tewas dalam kecelakaan akibat jalan rusak (berlobang) sebagaimana tertuang dalam Putusan Pengadilan Tinggi Jawa Barat Nomor 397/PEN/PDT/2017/PT.BDG.

Dalam tulisan ini, akan membahas tentang upaya yang dapat dilakukan oleh pengguna jalan untuk meminta 
pertanggungjawaban pidana penyelengara jalan sebagai akibat jalan yang rusak.

\section{METODE PENELITIAN}

Jenis penelitian ini adalah penelitian normatif. Penelitian hukum normatif juga mengacu kepad aturan-aturan hukum, normanorma hukum yang terdapat baik didalam ketentuan peraturan perundang-undangan maupun didalam putusan pengadilan. Sifat dari penelitian ini adalah deskriptif analisis artinya dalam penelitian ini penulis hanya ingin menggambarkan kebijakan-kebijakan yang dilakukan pihak yang membuat kebijakan dalam hal ini pemerintah sebagai penyelenggara dan pertanggungjawaban pidana akibat jalan rusak. Sumber data hukum dalam penelitian normatif adalah data kepustakaan. Prosedur pengambilan dan pengumpulan data dilakukan dengan cara studi kepustakaan (library research). Penelitian ini menggunakan analisis data secara kualitatif, melalui analisis berbagai peraturan perundangundangan yang berhubungan dengan objek penelitian.

\section{HASIL PENELITIAN dan PEMBAHASAN \\ 1. Kewenangan dan kewajiban penyelenggara jalan \\ Dalam Visi dan Misi Direktorat Jenderal} Bina Marga, Direktorat Jenderal Bina Marga sebagai penyelenggara jalan mempunyai tugas melaksanakan sebagian tugas pokok Departemen Pekerjaan Umum dalam perumusan dan pelaksanaan kebijakan dan standarisasi teknis bidang jalan, ${ }^{1}$ hal ini menunjukkan bahwa Direktorat Jenderal Bina Marga adalah lembaga yang bertanggungjawab atas penyelenggaraan jalan, hal ini di pertegas lagi dengan kewenangan Direktorat Jenderal Bina Marga yang dalam struktur program kerjanya terdapat kewenangan dalam melakukan penyelenggaraan jalan.

Jalan merupakan kekayaan atau aset yang sangat besar yang secara tradisional dikelola dan dibiayai oleh pemerintah sebagai layaknya prasarana pelayanan publik lainnya, dengan pelaksanaan pemeliharaan yang relatif kurang memadai. Pelaksanaan pemeliharaan jalan tersebut sebagai salah satu akibat dari rendahnya alokasi dana untuk pemeliharaan akan menyebabkan kerugian baik pemerintah maupun masyarakat. Hal ini akan terjadi

\footnotetext{
${ }^{1}$ Pedoman Umum Pengelolaan Lingkungan Hidup Bidang Jalan Nomor: 08/BM/05 yang merupakan bagian dari Pedoman Pengelolaan Lingkungan Hidup Bidang Jalan
}

penurunan kualitas kondisi jalan yang berdampak pada penurunan nilai kekayaan atau aset jalan. ${ }^{2}$

Sebagai salah satu sarana transportasi dalam kehidupan berbangsa peranan jaringan jalan pada hakekatnya menyangkut hajat hidup orang banyak. Dengan kedudukan dan peran jalan tersebut hak penguasaan jalan ada pada negara. Pemerintah sebagai pemegang kekuasaan peran pemerintahan negara memiliki kewajiban dalam penyelenggaran jalan secara umum.

Adapun masyarakat merupakan salah satu subjek pembangunan yang harus dilibatkan dan diberdayakan dalam melakukan penyelenggaraan jalan. Karena Selain itu masyarakat di samping memiliki hak masyarakat juga mempunyai kewajiban dalam penyelenggaraan jalan. Keterbatasan dana pemerintah khususnya untuk pemeliharaan jalan memerlukan keterlibatan peran masyarakat. Penyelenggara jalan adalah pihak yang melakukan pengaturan, pembinaan, pembangunan, dan pengawasan jalan sesuai dengan kewenanganya. ${ }^{3}$ Sedangkan yang di maksud dengan Penyelenggaraan Jalan pasal 14 adalah pihak yang melakukan pengaturan, pembinaan, pembangunan, dan pengawasan jalan sesuai dengan kewenanganya. Dapat di tarik kesimpulan bahwa penyelenggara jalan adalah Direktorat Jenderal Bina Marga sebagai penyelenggara jalan mempunyai tugas melaksanakan sebagian tugas pokok Departemen Pekerjaan Umum dalam perumusan dan pelaksanaan kebijakan dan standarisasi teknis bidang jalan, ${ }^{4}$ yang di tunjuk oleh pemerintah guna melakukan pembangunan, pengawasan dan pengaturan di bidang jalan. Pada sisi lain pemerintah daerah adalah gubernur, wali kota dan perangkat daerah sebagai unsur penyelenggara jalan.

Penyelenggara jalan dalam melakukan penyelenggaraan jalan mempunyai peran yang sangat penting dalam menentukan kebijakan, selain di berikan hak penyelenggara jalan juga di bebani kewajiban dalam melakukan penyelenggaraan jalan sehingga akan terjadi $c e k$

\footnotetext{
${ }^{2}$ Lampiran Peraturan Mentri Pekerjaan Umum Nomor 01/PRT/M/2012 tentang Pedoman Peran Masyarakat Dalam Pnyelenggaraan Jalan.

${ }^{3}$ Peraturan Mentri Pekerjaan Umum Nomor : $11 / \mathrm{PRT} / \mathrm{M} / 2010$ tentang Tata Cara Dan Persyaratan Layak Fungsi Jalan pasal 1 angka 6.

${ }^{4}$ Pedoman Konstruksi dan Bangunan No. 008/BM/2009 Pedoman Umum Pengelolaan Lingkungan Hidup Bidang Jalan.
} 
and balance. Adapun kewajiban pemerintah sebagai penyelenggara jalan tercantum dalam Undang-Undang Nomor 22 Tahun 2009 Tentang Lalu Lintas Dan Angkutan Jalan Pasal 238 (1) pemerintah menyediakan dan/atau memperbaiki pengaturan, sarana, dan prasarana lalu lintas yang menjadi penyebab kecelakaan. (2) pemerintah menyediakan alokasi dana untuk pencegahan dan penanganan kecelakaan lalu lintas.

Bahwa kewajiban Pemerintah sebagai penyelenggara utama pelayanan publik untuk melayani kebutuhan publik yang lebih baik sesuai dengan prinsip-prinsip tata kelola pemerintahan yang baik (good governance) dan demokratis merupakan amanat konstitusional Undang-Undang Dasar Negara Republik Indonesia Tahun 1945. Berbicara antara hak dan kewajiban penyelenggara dalam hal ini kewajiban penyelenggara jalan diatur dalam Undang-Undang Nomor 22 Tahun 2009 Tentang Lalu Lintas Dan Angkutan Jalan pasal 23 ayat (1) penyelenggara jalan dalam melakukan preservasi jalan dan/atau peningkatan kapasitas jalan wajib menjaga keamanan, keselamatan, ketetiban dan kelancaran lalu lintas dan angkutan jalan, jo pasal 24 (1) penyelenggara jalan wajib segera dan patut untuk memperbaiki jalan yang rusak yang dapat mengakibatkan kecelakaan lalu lintas. Jika dalam hal kewajiban penyelenggara jalan tidak dilaksanakan maka penyelenggara dapat di jatuhi sanksi pidana sesuai ketentuan Undang-Undang Nomor 22 Tahun 2009 Tentang Lalu Lintas Dan Angkutan Jalan pasal 273 ayat (1).

Adapun kewajiban penyelenggara jalan adalah sebagai berikut:

1. Memberikan fasilitas dan pelayanan kepada masyarakat

Penyelenggara jalan memberikan fasilitas dan pelayanan kepada masyarakat tentang hal yang berhubungan dengan penyelenggaraan jalan. Fasilitas dan pelayanan yang diberikan oleh penyelenggara jalan tersebut dapat dimanfaatkan penuh oleh masyarakat untuk memberikan peran dalam penyelenggaraan jalan sesuai dengan peraturan perundangundangan. Penyelenggara jalan wajib menyediakan fasilitas untuk masyarakat yang meliputi:
1) Penyediaan fungsi pelayanan masyarakat dalam penyelenggaraan jalan;
2) Penyediaan media komunikasi baik cetak maupun elektronik;
3) Penetapan standar operasi dan prosedur mekanisme pelaksanaan peran

masyarakat dalam penyelenggaraan jalan;

4) Pelaksanaan sosialisasi penyelenggaraan jalan.

Kemudian penyelenggara jalan wajib menyediakan pelayanan untuk masyarakat yang meliputi:

1) Penyediaan sistem informasi;

2) Penyampaian data dan informasi;

3) Penerimaan usulan, saran dan kritik;

4) Pelayanan kajian;

5) Pelayanan pengujian;

6) Pelaksanaan penelitian dan pengembangan;

7) Pemberian izin/rekomendasi/dispensasi pemanfaatan dan/atau penggunaan bagian-bagian jalan; dan

8) Penyediaan bimbingan dan penyuluhan kepada masyarakat dalam hal keterlibatan langsung masyarakat dalam penyelenggaraan jalan.

Penyediaan fungsi pelayanan masyarakat dalam penyelenggaraan jalan diinformasikan kepada masyarakat agar mudah diketahui keberadaannya. ${ }^{5}$

2. Menyediakan perlengkapan jalan

Setiap jalan yang digunakan untuk lalu lintas umum wajib dilengkapi dengan perlengkapan jalan yang berupa:

a) Rambu lalu lintas;

b) Marka jalan;

c) Alat pemberi isyarat lalu lintas;

d) Alat penerangan jalan;

e) Alat pengendali dan pengamanan jalan;

f) Fasilitas untuk sepeda, pejalan kaki dan penyandang cacat; dan

g) Fasilitas pendukung kegiatan lalu lintas dan angkutan jalan yang berada di jalan dan di luar badan jalan.

Penyediaan perlengkapan jalan tersebut diselenggarakan oleh:

a) Pemerintah untuk jalan nasional;

b) Pemerintah provinsi untuk jalan provinsi;

c) Pemerintah kabupaten/kota untuk jalan kabupaten/kota dan jalan desa; atau

d) Badan usaha jalan tol untuk jalan tol

3. Melakukan pengawasan

Wewenang pengawasan jalan secara umum meliputi pengawasan jalan nasional, jalan provinsi, jalan kabupaten/kota, dan jalan desa ada pada Menteri yang menyelenggarakan urusan pemerintahan di

${ }^{5}$ Pasal 6 Peraturan Menteri Pekerjaan Umum Nomor 01/PRT/M/2012 tanggal 16 Januari 2012 tentang Pedoman Peran Masyarakat Dalam Penyelenggaraan Jalan. 
bidang pekerjaan umum. Wewenang pengawasan jalan secara umum untuk jalan kabupaten/kota dan jalan desa dapat dilakukan oleh Gubernur berdasarkan penetapan Menteri yang menyelenggarakan urusan pemerintahan di bidang pekerjaan umum. Pengawasan jalan nasional merupakan kewenangan Menteri yang menyelenggarakan urusan pemerintahan di bidang pekerjaan umum. Pengawasan jalan provinsi merupakan kewenangan gubernur. Pengawasan jalan kabupaten dan jalan desa merupakan kewenangan Bupati, dan pengawasan jalan kota merupakan kewenangan Walikota. ${ }^{6}$

Berdasarkan kewajiban dan kewenangan penyelenggara jalan tersebut, maka menjadi hal yang sangat wajar beberapa kasus gugatan diakibatkan jalan yang rusak, banyak pihakpihak yang digugat, misalnya Menteri Pekerjaan Umum, Gubernur, Bupati/Walikota bahkan Dewan Perwakilan Rakyad Daerah juga digugat. Hal ini karena memang pihak-pihak tersebut merupakan pihak yang paling bertanggungjawab terhadap kondisi jalan yang rusak.

Dalam peraturan perundang-undangan sudah di atur secara jelas tentang kewenangan pemerintah dalam menyelenggarakan jalan, seperti Undang-Undang Nomor 38 Tahun 2004 Tentang Jalan Pasal 13 (1) penguasaan jalan ada pada Negara di lanjutkan ayat (2) penguasaan oleh Negara di maksud pada ayat (1) memberi wewenang kepada pemerintah dan pemerintah daerah untuk melaksanakan penyelenggaraan jalan. Kewenangan penyelenggaraan jalan dalam hal ini terbagi atas tiap pemerintahan mulai dari kewenangan pemerintah pusat, provinsi, kabupaten dan kota, semuanya mempunyai kewenangan tersendiri.

\section{Hak-hak Rakyat sebagai Pengguna Fasilitas Umum yang Dilindungi oleh Aturan Perundang-undangan \\ Dalam pengertian hukum, yang} dimaksud dengan hak adalah kepentingan hukum yang harus dilindungi oleh hukum, sedangkan kepentingan adalah tuntutan yang diharapkan untuk dipenuhi. Kepentingan pada hakikatnya mengandung kekuasaan yang dijamin dan dilindungi oleh hukum dalam melaksanakannya. Pada dasarnya hak bersumber dari 3 (tiga) hal. Pertama, dari kodrat manusia sebagai makhluk yang diciptakan oleh Tuhan. Sebagai makhluk ciptaan Tuhan,

${ }^{6}$ Peraturan Menteri Pekerjaan Umum Nomor 04/PRT/M2012 tanggal 25 Januari 2012 tentang Tata Cara Pengawasan Jalan. manusia mempunyai sejumlah hak sebagai manusia dan untuk mempertahankan kemanusiaannya. Hak inilah yang disebut dengan hak asasi. Kedua, hak yang lahir dari hukum, yaitu hak-hak yang diberikan oleh hukum negara kepada manusia dalam kedudukannya sebagai warga negara. Ketiga, hak yang lahir dari hubungan hukum antara seseorang dan orang lain melalui sebuah kontrak atau perjanjian. ${ }^{7}$

Setiap masyarakat mempunyai hak untuk tidak terancam keselamatannya atau terhadap jiwanya, hak merasa aman dan nyaman seperti yang di jelaskan undang-undang dasar 1945 pasal 34 (1). Begitu pula dengan perundang-undangan yang di bawahnya, bahwa undang-undang dasar adalah salah satu 4 pilar Negara kita, yang kemudian di jadian titik tolak ukur dalam pembuatan perundang-undangan lainya, peraturan perundang-undangan dibuat atas dasar kepentingan rakyat guna melindungi hak-hak dan kepentingan rakyat.

Rakyat atau masyarakat sebagai pemakai suatu barang dan jasa dalam perspektif hukum di Indonesia disebut dengan konsumen. Konsumen dalam perspektif Undang-Undang Perlindungan Konsumen adalah "setiap orang pemakai barang dan/atau jasa yang tersedia dalam masyarakat, baik bagi kepentingan diri sendiri, keluarga, orang lain, maupun makhluk hidup lain dan tidak untuk diperdagangkan". Berdasarkan pengertian tersebut, maka subyek yang disebut sebagai konsumen berarti setiap orang yang berstatus sebagai pemakai barang dan jasa. ${ }^{8}$

Istilah "orang" sebetulnya memunculkan keraguan, apakah hanya orang individual yang lazim disebut dengan natuurlijke persoon, atau termasuk juga badan hukum (recht person). Menurut AZ Nasution, yang dimaksud dengan orang adalah orang alami bukan badan hukum, sebab yang memakai, menggunakan dan atau memanfaatkan barang dan atau jasa untuk kepentingan diri sendiri, keluarga, orang lain maupun makhluk hidup lain tidak untuk

${ }^{7}$ Janus Sidabalok, 2010, Hukum Perlindungan Konsumen di Indonesia, Bandung: PT Citra Aditya Bakti, hlm. 35.

${ }^{8}$ Hesti Tiffany Fitri, "Perlindungan Konsumen Pengguna Jalan Ditinjau Dari Perspektif Undang-Undang Jalan Yang Memiliki Hubungan Saling Melengkapi Dengan Undang-Undang Lalu Lintas Dan Angkutan Jalan Serta Undang-Undang Perlindungan Konsumen". Tesis. Fakultas Hukum Universitas Indonesia Program Hukum Ekonomi, 2012, hlm. 41 . 
diperdagangkan hanyalah orang alami atau manusia. $^{9}$

Dalam hal masyarakat sebagai pengguna jalan yang mengalami kecelakaan akibat kondisi jalan yang rusak, maka rakyat yang telah melaksanakan kewajibannya yaitu membayar pajak, berhak untuk memperoleh ganti kerugian. Hak untuk memperoleh ganti kerugian dimaksudkan untuk memulihkan keadaan yang telah menjadi rusak (tidak seimbang) akibat adanya penggunaan barang atau jasa yang tidak memenuhi harapan pemakai. Hak ini sangat terkait dengan penggunaan produk yang telah merugikan konsumen, baik yang merupakan kerugian materi, maupun kerugian yang menyangkut diri sendiri (sakit, cacat bahkan kematian) pemakai. Untuk merealisasikan hak ini, tentu saja harus melalui prosedur tertentu, baik yang diselesaikan secara damai (diluar pengadilan) maupun yang diselesaikan melalui pengadilan. ${ }^{10}$

Terkait dengan hak-hak masyarakat sebagai konsumen yang menggunakan jalan, fasilitas jalan selama ini banyak dikeluhkan oleh masyarakat pengguna jalan, karena kenyataannya banyak dijumpai jalan-jalan yang rusak yaitu berlubang atau karena adanya galin dari perusahaan gas, PLN, perusahaan air minum, perusahaan telekomunikasi baik milik pemerintah maupun swasta, yang tidak diberi tanda atau bahkan penutupannya kurang rata yang berakibat terjadinya kecelakaan. Hal ini tentu saja berpotensi menimbulkan kecelakaan lalu lintas dan merugikan masyarakat.

Kerusakan jalan baik itu rusak berat maupun rusak ringan merugikan kepentingan masyarakat banyak, terutama perusahaan transportasi dan pengguna jalan. Kendaraan sulit melewati jalan yang rusak dan sangat berbahaya bagi pengguna jalan yang rusak yang melewatinya. Bukan hanya dapat menimbulkan korban jiwa, tetapi juga kerugian materil bagi pemilik kendaraan, kendaraan menjadi cepat rusak akibat melewati jalan berlubang. Jalan yang rusak menyebabkan kerusakan komponen kenderaan dan memperlambat perjalanan serta menyebabkan kecelekaan lalu lintas.

Kerusakan jalan berpotensi menghambat perputaran ekonomi, sebab menimbulkan penambahan biaya operasional transportasi yang dialami para pelaku ekonomi guna menutupi

${ }^{9} \mathrm{AZ}$ Nasution, 2011, Hukum Perlindungan Konsumen: Suatu Pengantar, Jakarta: Diadit Media, hlm. 5.

${ }^{10}$ Ahmadi Miru, 2011, Prinsip-prinsip Perlindungan Hukum Bagi Konsumen di Indonesia, Jakarta: PT RajaGrafindo Persada, hlm. 103-108. berbagai cost yang harus dipenuhi. Kerusakan jalan juga menyebabkan kandungan ibu hamil rentan terguncang dan terjadi pendarahan di perjalanan menuju rumah sakit. Kerusakan jalan juga sangat merugikan karena otomatis kerap terjadi antrian-antrian di jam-jam tertentu.

\section{Upaya yang Dapat Dilakukan oleh Korban/Pengguna Jalan Meminta Pertanggungjawaban Pidana Penyelenggara Jalan atas Terjadinya Kecelakaan Akibat Jalan Rusak}

Menurut Soerjono Soekanto bahwa faktor-faktor utama penyebab terjadinya kecelakaan lalu lintas diantaranya adalah faktor manusia, faktor kendaraan, dan faktor jalan. ${ }^{11}$ Oleh karenanya setiap pengguna jalan raya harus memperoleh jaminan perlindungan dari pemerintah.

Berdasarkan Pasal 28D (1) UndangUndang Dasar Negara Republik Indonesia Tahun 1945 yang merupakan sumber hukum bagi setiap undang-undang yang ada menerangkan bahwa negara memberikan jaminan kepada setiap warganya "Setiap orang berhak atas pengakuan, jaminan, perlindungan, dan kepastian hukum yang adil serta perlakuan yang sama di hadapan hukum".

Pasal 28I ayat (5) Undang-Undang Dasar 1945 berbunyi: "untuk menegakkan dan melindungi hak asasi manusia sesuai dengan prinsip negara hukum yang demokratis, maka pelaksanaan hak asasi manusia dijamin, diatur, dan dituangkan dalam peraturan perundangundangan". Undang-undang yang khusus mengatur mengenai lalu lintas adalah UndangUndang Nomor 22 Tahun 2009 Tentang Lalu Lintas dan Angkutan Jalan. Dikeluarkannya undang-undang ini bertujuan agar lalu lintas dan angkutan jalan mempunyai peran strategis dalam mendukung pembangunan dan integritas nasional sebagai bagian dari upaya memajukan kesejahteraan umum sebagaimana yang diamanatkan oleh Undang-Undang Dasar Negara Republik Indonesia dan juga merupakan bagian dari sistem transportasi nasional yang harus dikembangkan potensi dan perannya untuk mewujudkan keamanan, keselamatan, ketertiban, dan kelancaran berlalu lintas.

Pembangunan serta pemeliharaan jalan merupakan kewajiban dan kewenangan

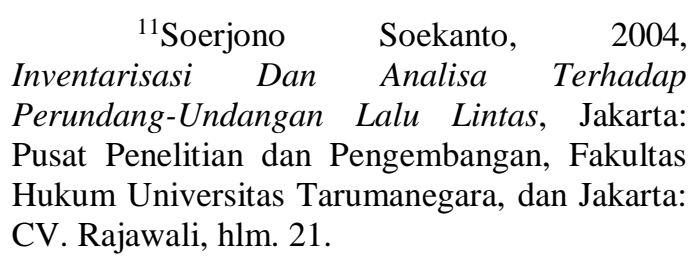


pemerintah selaku penguasa, apabila pembangunan dan perawatan jalan yang dilakukan oleh pemerintah rusak dan tidak segera diperbaiki hingga menimbulkan kerugian materil hingga korban manusia, apakah negara dalam hal ini tidak bisa dimintai pertanggung jawaban atas kelalainya untuk melakukan kewajiban merawat jalan, terlebih lagi jika yang menjadi korban adalah individu yang taat hukum dan pajak. masyarakat sudah memenuhi kewajibanya melengkapi kelengkapan berkendara sesuai dengan peraturan berlalulintas dan juga masyarakat memenuhi kewajibanya membayar pajak terhadap negara, maka dari itu negara harus memberikan pelayanan yang baik bagi individu yang taat hukum dan pajak seperti melakukan perawatan jalan.

Kerusakan jalan yang ada kurang mendapat perhatian yang serius dari pemerintah. Hal tersebut terbukti dengan dibiarkannya kerusakan ini selama berbulan-bulan sampai bertahun-tahun lamanya. Kerusakan jalan ini seperti kerusakan jalan pada umumnya, yaitu jalan yang retak-retak hingga jalan berlobang. Kerusakan jalan seperti ini bisa mengancam keselamatan para pengendara sepeda motor, mulai dari kecelakaan ringan hingga merenggut nyawa para pengguna jalan. Kecelakaan lalu lintas, baik karana faktor kendaraan maupun faktor kondisi jalan sering kali menimbulkan korban. Oleh karena itu mereka yang menjadi korban, terutama korban kecelakaan karana faktor kondisi jalan harus mendapatkan perlindungan hukum.

Kecelakaan Lalu Lintas menurut Undang-Undang Nomor 22 tahun 2009 tentang Lalu Lintas dan Angkutan Jalan Pasal 1 butir 24 adalah suatu peristiwa di jalan yang tidak diduga dan tidak disengaja melibatkan kendaraan dengan atau tanpa pengguna jalan lain yang mengakibatkan korban manusia dan atau kerugian harta benda. Dalam kecelakaan lalu lintas yang sering terjadi seringkali korban tidak mendapatkan perlindungan hukum sebagaimana yang seharusnya didapatkan oleh korban kecelakaan lalu lintas.

Undang-undang Lalu Lintas dan Angkutan Jalan, pasal 24 menegaskan bahwa penyelenggara jalan wajib segera dan patut untuk memperbaiki jalan yang rusak agar tidak mengakibatkan kecelakaan lalu lintas jalan. Apabila belum diperbaiki, maka jalan yang rusak harus diberi tanda atau rambu. Penyelenggara jalan tersebut menurut pasal 26 ayat (1) huruf c yaitu Pemerintah Kabupaten/Kota untuk jalan Kabupaten/Kota. Pasal 240 huruf b menyatakan bahwa korban kecelakaan lalu lintas jalan berhak mendapat ganti kerugian dari pihak yang bertanggung jawab atas terjadinya kecelakaan lalu lintas jalan.

Kecelakaan yang telah berakibat kepada kerugian pengguna jalan merupakan dampak dari ketersediaan sarana dan prasarana lalu lintas jalan yang kurang lengkap dan tepat. Gugatan masyarakat sebagai pengguna jalan yang merasa dirugikan karena jalan rusak pernah terjadi di Pemerintah Kota Bandung telah yang mengalami kecelakaan lalu lintas jalan dan kerugian di wilayah Kota Bandung.

Gugatan masyarakat kepada Pemerintah Kota Bandung dilakukan oleh warga Bandung melalui dua cara. Pertama, melalui mekanisme citizen law suit. Pengertian dari citizen law suit adalah gugatan warga Negara yang ditujukan kepada Pemerintah atau negara akibat pelanggaran-pelanggaran hukum yang dilakukan negara dan dianggap merugikan kepentingan publik. ${ }^{12}$ Gugatan citizen law suit merupakan sebuah gugatan yang berkaitan dengan kepentingan umum. Kedua, melalui gugatan perbuatan melawan hukum. Pada citizen law suit, gugatan dilakukan oleh korban kecelakaan lalu lintas jalan yang diduga diakibatkan karena tidak terakomodasi sarana dan prasarana lalu lintas jalan.

Gugatan yang diajukan kepada Pemerintah Kota Bandung adalah gugatan yang diajukan oleh pihak Tim Advokat Pengawal Pemulihan Hak Warga Kota Bandung. Gugatan tersebut diajukan berkaitan dengan kondisi jalan di Kota Bandung yang buruk, sehingga telah mengakibatkan jumlah kecelakaan yang terjadi di Kota Bandung semakin bertambah banyak. Gugatan tersebut diajukan kepada Walikota Bandung, Kepala Dinas Bina Marga, Kementerian Pekerjaan Umum, Pemerintah Kota Bandung, dan DPRD Kota Bandung. Penyampaian gugatan tersebut dilakukan pada tanggal 25 Juni 2013 dengan Nomor perkara 299/PDT/G/2013/PN.BDG.

Selain Pemerintah Kota Bandung, salah satu kementerian di Indonesia yang pernah mengalami gugatan yaitu Kementerian Pekerjaan Umum. Gugatan tersebut bermula ketika adik dari Arik S. Wartono warga Desa Kembangan yang mengalami kecelakaan yang diakibatkan jalan di Bandjarsari, Gresik rusak. Akibat kecelakaan tersebut adik dari Arik S. Wartono yang bernama Adi mengalami gegar otak, sehingga mengajukan gugatan dengan kerugian material sebesar Rp.47.500,000 (empat puluh tujuh juta lima ratus rupiah) dan kerugian immaterial sebesar Rp.10.000.000.000 (sepuluh

${ }^{12}$ Henry C. Black, 1989, Blacks Law Dictionary, Harvard: Harvard Publishing, hlm. 289. 
milyar rupiah). Penggugat mengajukan gugatannya melalui Lembaga Advokasi Masyarakat. Penggugat beralasan bahwa pihak yang digugat merupakan pemegang tanggung jawab terhadap penyelenggara, perawatan, dan perbaikan jalan sebagaimana telah diatur dalam Undang-undang Lalu Lintas dan Angkutan Jalan, dan Undang-undang Jalan.

Perbedaan antara gugatan yang diajukan di Kota Bandung dan gugatan yang diajukan di Gresik terdapat pada bentuk gugatannya yaitu gugatan yang diajukan oleh warga Bandung melalui Tim Advokasi Masyarakat Bandung merupakan gugatan yang dikategorikan sebagai citizen law suit. Pada kasus gugatan yang terjadi di Gresik merupakan gugatan perorangan.

Dalam perspektif lain yang dapat dilakukan oleh rakyat sebagai pengguna jalan akibat jalan rusak yang menimbulkan korban adalah melakukan tanggung gugat terhadap Negara. J.H. Nieuwenhuis, berpendapat bahwa tanggung gugat merupakan kewajiban untuk menanggung ganti kerugian sebagai akibat pelanggaran norma. Perbuatan melanggar norma tersebut dapat terjadi disebabkan karena perbuatan melawan hukum dan wanprestasi. ${ }^{13}$

Tanggung gugat merujuk kepada posisi seseorang atau badan hukum yang dipandang harus membayar suatu bentuk kompensasi atau ganti rugi setelah adanya peristiwa hukum atau tindakan hukum. misalnya harus membayar ganti kerugian kepada orang atau badan hukum lain karena telah melakukan perbuatan melanggar hukum onrechtmatige daad sehingga menimbulkan kerugian bagi orang atau badan hukum lain tersebut. Istilah tanggung gugat berada dalam ruang lingkup hukum privat. ${ }^{14}$

Adanya gugatan rakyat sebagai pengguna jalan terhadap penyelenggara jalan dalam hal ini pemerintah ketika ada jalan rusak, sebenarnya menuntut tanggungjawab negara. Menyediakan serta memperbaiki jalan rusak merupakan wewenang dan tanggung jawab pemerintah/negara.

Menurut Thomas Hobbes (1588-1406) sebagaimana dikutip oleh Soehino negara adalah suatu tubuh yang dibuat oleh orang banyak beramai-ramai, yang masing-masing berjanji akan memakainya menjadi alat untuk

${ }^{13}$ J.H. Nieuwenhuis, 1978, Hoofdstukken Verbintenissenrecht, Terjemahan, Surabaya: Universitas Airlangga, hlm. 135.

${ }^{14}$ Peter Mahmud Marzuki, 2008, Pengantar Ilmu Hukum, Jakarta: Kencana Prenada Media, hlm. 258. keamanan dan perlindungan bagi mereka. ${ }^{15}$ Menurut J.J. Rousseau (1712-1778) Negara adalah perserikatan dari rakyak bersama-sama yang melindungi dan mempertahankan hak masing-masing diri dan harta benda anggotaanggota yang tetap hidup dengan bebas merdeka. ${ }^{16}$

Upaya lain yang dapat dilakukan oleh korban atas terjadinya jalan rusak bisa menggunakan cara gugatan Legal Standing. Membicarakan gugatan Legal Standing pada umumnya selalu dikaitkan dengan gugatan Class Action, karena baik gugatan Legal Standing maupun Class Action, pada hakekatnya merupakan bentuk gugatan perwakilan kelompok, yaitu gugatan yang mewakili kepentingan publik atau kelompok tertentu dalam masyarakat. Gugatan perwakilan kelompok ini pada umumnya diajukan oleh kalangan masyarakat maupun Organisasi Non Pemerintah (ORNOP) yang bertindak mewakili kepentingan publik atau kelompok masyarakat tertentu dalam upaya untuk memperjuangkan hak-hak dan kepentingan mereka yang dirugikan. ${ }^{17}$

Pengaturan Legal Standing dalam aturan Hukum Indonesia secara materiil telah mengatur hak gugat organisasi (legal standing/ Ius standing), namun hukum acara yang ditunjuk sebagai hukum formil yang mempertahankan hukum materiil tersebut belum diatur. Sedangkan pengaturan Class Action dalam aturan Hukum Indonesia diatur dalam PERMA No. 1 Tahun 2002 tentang Acara Gugatan Perwakilan Kelompok. Gugatan Perwakilan Kelompok atau Class Action merupakan suatu prosedur pengajuan gugatan, dimana 1 (satu) orang atau lebih yang mewakili kelompok mengajukan gugatan untuk dirinya sendiri dan sekaligus mewakili sekelompok orang yang jumlahnya banyak, yang memiliki kesamaan fakta atau kesamaan dasar hukum antara wakil kelompok dan anggota kelompoknya.

Selain upaya gugatan yang telah dijelaskan diatas, korban/pengguna jalan bisa melakukan langkah hukum untuk meminta pertanggungjawaban pidana penyelenggara

${ }^{15}$ Titik Triwulan T., Ismu Gunadi Widodo, 2011, Hukum Tata Usaha Negara dan Hukum Acara Peradilan Tata Usaha Negara Indonesia, Jakarta: Kencana, hlm. 3.

${ }^{16}$ Ibid.

${ }^{17}$ Bambang Sutiyoso, "Implementasi Gugatan Legal Standing dan Class Action Dalam Praktik Peradilan Di Indonesia", Jurnal Hukum, Volume 11, Nomor 26, Tahun 2006, hlm. 2 . 
jalan akibat jalan rusak kepada Pemerintah (penyelenggara jalan) yaitu korban/pengguna jalan segera melaporkan pihak penyelenggara jalan ke Kepolisian setempat dimana korban/pengguna jalan mengalami kecelakaan dan selanjutnya pihak Kepolisian akan melakukan proses penyelidikan dan penyidikan, apakah benar kecelakaan tersebut disebabkan oleh kerusakan jalan atau kelalaian pengendara. Apabila terbukti kecelakaan tersebut memang karena jalan rusak, maka penyelenggara jalan dapat dipidana sebagaimana tertuang dalam Pasal 273 ayat 1 sampai dengan ayat 3 UULLAJ.

\section{SIMPULAN dan SARAN}

\section{Simpulan}

Bahwa upaya yang dapat dilakukan oleh korban/pengguna jalan meminta pertanggungjawaban pidana penyelenggara jalan atas terjadinya kecelakaan jalan akibat jalan rusak adalah melalui mekanisme citizen law suit. Pengertian dari citizen law suit adalah gugatan warga Negara yang ditujukan kepada Pemerintah atau negara akibat pelanggaran-pelanggaran hukum yang dilakukan negara dan dianggap merugikan kepentingan publik. Upaya lainnya adalah tanggung gugat merupakan kewajiban untuk menanggung ganti kerugian sebagai akibat pelanggaran norma. Perbuatan melanggar norma tersebut dapat terjadi disebabkan karena perbuatan melawan hukum dan wanprestasi. Upaya Legal Standing dan Class Action juga bisa dilakukan oleh korban/pengguna jalan. Pengaturan Legal Standing dalam aturan Hukum Indonesia secara materiil telah mengatur hak gugat organisasi (legal standing/ Ius standing), sedangkan pengaturan Class Action dalam aturan Hukum Indonesia diatur dalam PERMA No. 1 Tahun 2002 tentang Acara Gugatan Perwakilan Kelompok. Selain upaya gugatan tersebut, korban/pengguna jalan bisa melakukan langkah hukum untuk meminta pertanggungjawaban pidana penyelenggara jalan akibat jalan rusak kepada Pemerintah (penyelenggara jalan) yaitu korban/pengguna jalan segera melaporkan pihak penyelenggara jalan ke Kepolisian setempat dimana korban/pengguna jalan mengalami kecelakaan.

\section{Saran}

Seharusnya warga negara memahami bahwa mereka mempunyai hak untuk menuntut pertanggungjawaban pidana kepada penyelenggara jalan yang membiarkan jalan rusak, yang dapat menyebabkan terjadinya kecelakaan. Bagi penyelenggara jalan, seharusnya lebih aktif dengan cara melihat langsung kondisi jalan yang rusak dilapangan serta dalam waktu yang singkat untuk segera memperbaiki jalan yang rusak tersebut.

\section{DAFTAR PUSTAKA}

Ahmadi Miru, 2011, Prinsip-prinsip Perlindungan Hukum Bagi Konsumen di Indonesia, Jakarta: PT RajaGrafindo Persada.

Black, Henry C., 1989, Blacks Law Dictionary, Harvard: Harvard Publishing.

Nasution, AZ, 2011, Hukum Perlindungan Konsumen: Suatu Pengantar, Jakarta: Diadit Media.

Nieuwenhuis, J.H., 1978, Hoofdstukken Verbintenissenrecht, Terjemahan, Surabaya: Universitas Airlangga.

Peter Mahmud Marzuki, 2008, Pengantar Ilmu Hukum, Jakarta: Kencana Prenada Media.

Sidabalok, Janus, 2010, Hukum Perlindungan Konsumen di Indonesia, Bandung: PT Citra Aditya Bakti.

Soerjono Soekanto, 2004, Inventarisasi Dan Analisa Terhadap PerundangUndangan Lalu Lintas, Jakarta: Pusat Penelitian dan Pengembangan, Fakultas Hukum Universitas Tarumanegara, dan Jakarta: CV. Rajawali.

Titik Triwulan T., Ismu Gunadi Widodo, 2011, Hukum Tata Usaha Negara dan Hukum Acara Peradilan Tata Usaha Negara Indonesia, Jakarta: Kencana.

\section{Peraturan Perundang-undangan}

Kitab Undang-Undang Hukum Pidana.

Undang-Undang Republik Indonesia Nomor 38 Tahun 2004 tentang Jalan.

Undang-Undang Republik Indonesia Nomor 22 Tahun 2009 tentang Lalu Lintas dan Angkutan Jalan.

Pedoman Umum Pengelolaan Lingkungan Hidup Bidang Jalan Nomor: 08/BM/05 yang merupakan bagian dari Pedoman Pengelolaan Lingkungan Hidup Bidang Jalan.

Lampiran Peraturan Mentri Pekerjaan Umum Nomor 01/PRT/M/2012 tentang 
Pedoman Peran Masyarakat Dalam Pnyelenggaraan Jalan.

Peraturan Mentri Pekerjaan Umum Nomor : 11 /PRT/M/2010 tentang Tata Cara Dan Persyaratan Layak Fungsi Jalan pasal 1 angka 6.

Pedoman Konstruksi dan Bangunan No. 008/BM/2009 Pedoman Umum Pengelolaan Lingkungan Hidup Bidang Jalan.

Pasal 6 Peraturan Menteri Pekerjaan Umum Nomor 01/PRT/M/2012 tanggal 16 Januari 2012 tentang Pedoman Peran Masyarakat Dalam Penyelenggaraan Jalan.

Peraturan Menteri Pekerjaan Umum Nomor 04/PRT/M2012 tanggal 25 Januari 2012 tentang Tata Cara Pengawasan Jalan.

\section{Tesis}

Hesti Tiffany Fitri, "Perlindungan Konsumen Pengguna Jalan Ditinjau Dari Perspektif Undang-Undang Jalan Yang Memiliki Hubungan Saling Melengkapi Dengan Undang-Undang Lalu Lintas Dan Angkutan Jalan Serta Undang-Undang Perlindungan Konsumen". Tesis. Fakultas Hukum Universitas Indonesia Program Hukum Ekonomi, 2012.

\section{Jurnal}

Bambang Sutiyoso, "Implementasi Gugatan Legal Standing dan Class Action Dalam Praktik Peradilan Di Indonesia", Jurnal Hukum, Volume 11, Nomor 26, Tahun 2006. 